\title{
A Study of Key Audit Matters Disclosure
}

\author{
Hui Li \\ School of Management, Jinan University, Guangzhou, China \\ Email: hui990161939@126.com
}

How to cite this paper: Li, H. (2020). A Study of Key Audit Matters Disclosure. Modern Economy, 11, 399-406. https://doi.org/10.4236/me.2020.112030

Received: January 16, 2020

Accepted: February 16, 2020

Published: February 19, 2020

Copyright $\odot 2020$ by author(s) and Scientific Research Publishing Inc. This work is licensed under the Creative Commons Attribution International License (CC BY 4.0).

http://creativecommons.org/licenses/by/4.0/

\begin{abstract}
With the continuous development of the capital market, the quality requirements for the audit reports of listed companies are becoming stricter and stricter. On December 23, 2016, China officially released the auditing standards of China certified public accountants no.1504-communicating key audit matters in audit reports. Listed companies listed on $\mathrm{A}+\mathrm{H}$ shares implemented the new standards in their financial reports from January 1, 2017, and fully implemented standard 1504 from January 1, 2018. Under the new standards, the audit reports of listed companies disclose the key audit matters that have significant impact during the current audit process. This paper studies the format, content and quantity of disclosure of key audit matters, and analyzes the disclosure of key audit matters of China's A-share listed companies from 2016 to 2018 and summarizes the impact of disclosure of key audit matters from three aspects: users of financial reports, auditors and the audited entity.
\end{abstract}

\section{Keywords}

Key Audit Matters Disclosure, Reporter Users, Auditor, Audited Entity

\section{Introduction}

In recent years, economic globalization has promoted the increase of accounting estimation and judgment, the increasing complexity and difficulty of understanding financial statements (PCAOB, 2016), coupled with the failure of audit early warning mechanism in the financial crisis. The theoretical and practical circles gradually found that the traditional disclosure method of audit reports could no longer meet the increasing information demand of the capital market (PCAOB, 2016), and its binary method of audit quality (qualified or unqualified) also led to the lack of effective incentives for quality improvement in the audit market (Francis, 2011). Therefore, countries in turn carry out the audit report reform, requiring auditors to disclose the most important matters for the current 
financial statement audit, aiming at disclosing important risks in financial statements to investors, reducing the expectation gap of traditional audit reports, increasing information content and improving audit quality. In 2011 International Auditing and Assurance Standards Board (IAASB) initiated the reform of audit report standards. Then IAASB released a draft of the report guidelines for comment in 2013. Finally, IAASB released a series of audit report standards in January 2015 on the basis of years of soliciting opinions and adopted new audit report standards instead of the traditional audit report model.

In order to maintain the continuous and comprehensive convergence of China's auditing standards with international standards, the Chinese Institute of Certified Public Accountants has drafted 12 standards such as "Chinese Certified Public Accountants Auditing Standards No. 1504-Communication of Key Audit Matters in Audit Reports". These guidelines require that the audit report for $\mathrm{A}+\mathrm{H}$ share companies for use in the Mainland shall be implemented from January 1, 2017. For listed companies whose stocks are traded on the Shanghai and Shenzhen stock exchanges (i.e., main board companies), small and medium-sized board companies, and GEM companies, including companies listed on the domestic and overseas stock exchanges other than $\mathrm{A}+\mathrm{H}$ shares, companies applying for initial public offerings (i.e., IPO company), its financial statement auditing business shall implement this approval rule from January 1, 2018.

According to the relevant provisions of the auditing standards, key audit matters refer to those that the certified public accountant considers most important to the current financial statement audit according to his/her professional judgment. The confirmation of key audit matters is that the auditor selects the matters that the auditor has focused on in the audit process from the matters communicated with the management layer, then selects the most important matters from the matters focused on, and finally communicates in the audit report in a standardized format. Key audit matters are a kind of personalized language for the specific situation of the audited entity. It is not a general and undifferentiated formula. The reformed audit report requires not only the disclosure of key audit matters, but also the explanation of the reasons for identifying them as key audit matters and the audit response procedures of auditors. In other words, the professional judgment process and professional competence of auditors will be presented to the public, providing a reference for the public to have a deep understanding of the audit process and evaluate the work of auditors.

This paper studies the format, content and quantity of disclosure of key audit matters, and analyzes the disclosure of key audit matters of China's A-share listed companies from 2016 to 2018 and summarizes the impact of disclosure of key audit matters from three aspects: users of financial reports, auditors and the audited entity. This paper contributes to the literature on KAM disclosures in several ways. First, this paper summarizes the main contents of key audit matters of A-share listed companies from 2016 to 2018. It can help report users better understand the background and content of key audit matters. Secondly, this study reviews the research progress of key audit matters and can provide theo- 
retical reference for subsequent research.

\section{Key Audit Matters Disclosure}

\subsection{The Format of Key Audit Matters}

The key audit matters include the introduction paragraph and the body paragraph. The key audit matters are described item by item, which can be sorted according to the priority of importance and can also be disclosed according to the sequence of relevant items disclosed in the notes to financial statements. When communicating key audit matters in the audit report, certified public accountants shall pay attention to the completeness and appropriateness of matters and elements and shall also pay attention to the use of appropriate language and wording.

In 2016, 90 companies cross-listed in both mainland China A-share market and Hong Kong $\mathrm{H}$-share market start to comply with the new rule and the next year it applies to all the companies in Chinese exchanges (including the Mainland and Hong Kong). Thus, we have data available to inspect how auditors disclose KAMs. Table 1 shows the industry and number distribution of listed companies that disclose key audit matters in A-shares of Shanghai and Shenzhen stock exchanges from 2016 to 2018. According to the industry distribution, we can find that most of China's A-share listed companies are in industrial, followed by public utilities.

\subsection{The Number of Key Audit Matters}

CSA 1504 does not specify the number of key items to be disclosed. Due to differences in business and industry environment, as well as differences in the size and complexity of the auditees, certified public accountants should make appropriate and reasonable disclosure based on the actual situation of the auditees and their professional judgment ability. Generally speaking, the larger the size of the audited entity and the more complex the business, the more key audit matters are disclosed, and vice versa. However, the principle of moderation should be paid attention to in the disclosure. If the quantity is too large, it cannot reflect

Table 1. Summary statistics of listed companies.

\begin{tabular}{ccccc}
\hline Industry Code & Industry & 2016 & 2017 & $\mathbf{2 0 1 8}$ \\
\hline 0002 & Public utilities & 14 & 596 & 615 \\
0006 & Business & 1 & 173 & 170 \\
0005 & Industrial & 47 & 2329 & 2393 \\
0003 & Real estate & 6 & 186 & 187 \\
0004 & Comprehensive & 0 & 90 & 101 \\
0001 & Financial & 22 & 87 & 3553 \\
\hline
\end{tabular}


the "most important". If the quantity is too small, it cannot give play to the role of the new standards in enhancing the transparency of audit work and improving the relevance of audit report content, so as to achieve the expected reform effect.

Table 2 lists the number of the KAM disclosures, shows that $40 \%$ client firms receive three KAMs in 2016, nearly 25\% receive two KAMs, $20 \%$ receive one $\mathrm{KAM}$, and the rest $15 \%$ receive four or five KAMs. In 2017 when all listed companies were required to disclose KAMs, about $64 \%$ client firms receive two KAMs, about $33 \%$ receive one or three KAMs. Less than $3 \%$ firms receive more than three KAMs. On average, 64\% sample clients' auditors report two KAMs.

\subsection{The Content of Key Audit Matters}

The key audit matters must be those contained in the financial report and those required by the public. Different subjects involved in key audit matters can be classified from the following two aspects. The first category is directly related to the financial report: 1) areas of significant risk assessed by the auditor; 2) areas of management's major judgments designed in financial reports. The second category is directly related to the auditor's work: 1) areas that occupy more of the auditor's time and energy; 2) areas involving the auditor's important professional judgment, such as goodwill, financial instruments, revenue recognition, etc.

Table 3 lists the top five KAM topics that auditors often report on. The most popular topic was revenue recognition. This high frequency is due in part to new

Table 2. The number of key audit matters.

\begin{tabular}{cccc}
\hline Number & 2016 & 2017 & 2018 \\
\hline 1 & $18(20.00 \%)$ & $533(15.40 \%)$ & $526(14.80 \%)$ \\
2 & $22(24.45 \%)$ & $2212(63.91 \%)$ & $2280(64.17 \%)$ \\
3 & $36(40.00 \%)$ & $623(18.00 \%)$ & $640(18.01 \%)$ \\
4 & $12(13.33 \%)$ & $76(2.20 \%)$ & $98(2.76 \%)$ \\
5 & $2(2.22 \%)$ & $13(0.38 \%)$ & $8(0.23 \%)$ \\
6 & 0 & $4(0.11 \%)$ & $1(0.03 \%)$ \\
Total firms & $90(100 \%)$ & $3461(100 \%)$ & $3553(100 \%)$
\end{tabular}

Table 3. The topic of key audit matters.

\begin{tabular}{cccc}
\hline KAM topical category & $\mathbf{2 0 1 6}$ & $\mathbf{2 0 1 7}$ & $\mathbf{2 0 1 8}$ \\
\hline Revenue recognition & 26 & 2323 & 2275 \\
Accounts receivable allowance & 24 & 1267 & 1273 \\
Goodwill impairment & 15 & 816 & 826 \\
Inventory write-down & 15 & 679 & 700 \\
PPE impairment & 21 & 168 & 210 \\
\hline
\end{tabular}


revenue recognition standards that took effect in 2017. In fact, in 2016, before the new standards were introduced, the topic had become the most frequently mentioned by auditors. The second hot topic was accounts receivable allowance. On this topic, some companies use "recoverability", some use "provision for bad debt", and others use "impairment", regardless of whether a particular customer is involved. Further analysis revealed that whether it was "accounts receivable", "goodwill", "inventory" or, finally, "fixed assets", most of these accounts which were involved in the key audit events were related to the impairment of assets.

\section{What Do Key Audit Matters Disclosure Affect?}

\subsection{The Impact on Report User}

The purpose of adding key audit matters is to disclose financial reporting risks. In theory, the disclosure of key audit matters enables the users of the expected statements to know the matters that the auditor has focused on in the audit process and the relevant audit response procedures, thus increasing the information content of the audit report. Sirois et al. (2018) find that KAMs have attention directing impact, in that participants access KAM-related disclosures more rapidly and pay relatively more attention to them when KAMs are communicated in the auditor's report.

However, some scholars are skeptical about whether key audit items can really bring about information increment. First of all, although the situation of the auditees may change from year to year, the continuous disclosure of some key audit items in the next year is not uncommon. At this time, whether the information increment can be sustained is a challenge. Almulla \& Bradbury (2019) examine the impact of the enhanced auditor's report (ISA 701) in New Zealand on audit effort, audit quality, client disclosures and investors. They find no incremental affect related to the introduction of KAM disclosures. Secondly, the disclosure of key audit items may also lead to information redundancy, making it difficult for users to identify useful information. Sirois et al. (2018) found that key audit matters would guide the attention of the experimenter. Increasing the disclosure of key audit items would increase the attention of the experimenter to the disclosure of relevant financial statements, but also reduce the attention of the experimenter to the rest of the financial statements. Finally, due to the differences in the professional ability of report users, there will be difficulties in information interpretation. The research of Köhler et al. (2016) found that the influence of investor professionalism on the interpretation of new audit reports cannot be ignored. Compared with professional investors, non-professional investors have difficulties in dealing with information on key audit matters, which leads to the failure of improved audit reports to increase communication value after the deadline. Therefore, whether key audit matters can increase the content of information remains to be further studied.

\subsection{The Impact on Auditors}

The reform of audit report may bring about the change of audit responsibility 
for auditors. Audit practitioners, academics, and attorneys have expressed concern that disclosing key audit matters (KAMs) will increase jurors' auditor liability judgments when auditors fail to detect misstatements. In contrast, Brasel et al. (2016) provide theory and experimental evidence that KAM disclosures, under certain conditions, reduce auditor liability judgments. First, key audit matters act as a warning to investors to pay attention to such matters, and investors assume they are auditors. Reasonable and necessary measures taken to avoid material misstatement can be reduced to a certain extent even if material misstatement later occurs. Secondly, the key audit matters focus on matters of auditors in the audit process, the key audit matters disclosed to increase investors' understanding of audit work, which involves more major matters of audit judgment. Investors may perceive the auditor to make appropriate decisions is not easy, so investors perception of auditor liability will reduce to a certain extent. Finally, the disclosure of key audit items will enable investors to perceive that the auditor is careful and diligent in the audit work, thus reduce investor perception of audit to some extent.

Moreover, some scholars believe that key audit matters will increase audit fees. In the study of increasing the audit fee, we mainly start from increasing the audit cost and increasing the audit risk. The disclosure of key audit matters improves audit transparency, auditors will be more cautious about audit risks, expand the scope of substantive audit procedures, and increase audit costs. Some scholars also found that key audit matters will not increase audit fees. The possible reason is that the disclosure of key audit matters is gradually compulsory, which will not lead to the increase of audit fees. Reid et al. (2019) took advantage of recent changes in UK audit reports and found no empirical evidence of significant changes in audit quality or audit costs when implementing the new reporting system.

In addition to the impact of key audit matters on auditor responsibilities and audit fees, it also affects audit quality, but research conclusions have not yet been reached. Some scholars argue that the disclosure of the key audit matters will make judges which tend to think that the auditor and stakeholder need more legal responsibility, face a higher risk of litigation, so this allows the auditor to make more cautious, certified public accountants to audit work to optimize and improve the quality of audit (Kachelmeier \& Valentine, 2017). However, some scholars found that key audit items did not improve audit quality through empirical tests. The empirical findings are not found in the implementation of the new reporting system. There is empirical evidence of major changes in audit quality (Reid et al., 2019).

\subsection{The Impact on the Audited Entity}

First, the disclosure of key audit matters can reduce earnings management level by improving audit quality. On the one hand, high-quality audit can better discover the company's earnings management behavior, thus inhibiting the company's earnings management. On the other hand, high quality auditing has a de- 
terrent effect, making the auditees afraid, thus reducing earnings management behavior. Secondly, the disclosure of key audit matters strengthens the communication with the management layer, which makes the management layer pay more attention to whether the financial statements fairly reflect the enterprise operating conditions in accordance with the accounting standards for enterprises and make adjustments in accordance with the adjustment of certified public accountants to improve the quality of financial statements.

In addition, studies have proved that the disclosure of key audit matters can change managers' decision-making. Bentley et al. (2018) conduct three experiments in two different decision settings (whether to use derivatives or issue a new loan program) and test how key audit matters disclosure changes managers' decisions based on the risk implications of the decision. Their results suggest that KAM disclosures elicit strategic managerial responses in such a way that may encourage risk-increasing activities and reduce risk-decreasing activities.

Disclosure of key audit items also has an impact on the attitudes of the audited firm, including the willingness of management to communicate with the auditor and the level of compliance of the audited firm. In the improved audit report, in order to minimize the adverse impact on the company, the management of the auditee makes the auditor more aware of the intended disclosure and the company's position, and will communicate with the auditor more actively. When the relationship between the management and the auditors is normal, the previous communication frequency may not be enough. After the audit report is reformed, the communication frequency will increase significantly and the communication willingness will be significantly enhanced.

\section{Future Research Prospects}

It can be found from the above research that most of the studies took American and British companies as samples. This is because China didn't implement the new auditing standards until 2017, so the sample period is relatively short and the overall sample size is relatively small. Therefore, differences in samples from different regions may lead to inconsistencies in existing research conclusions. In fact, there's a lot of room for improvement in future research. First of all, the future research direction should focus on the impact path and mechanism of key audit matters, conduct theoretical analysis from different perspectives and disciplines, and enrich theoretical research. Second, existing studies focus on the impact of key audit matters on investors, while ignoring the impact on other stakeholders. Future studies should also consider the impact of key audit matters on other stakeholders. Finally, the sample range and sample size can be appropriately increased in future studies to enhance the robustness of the research conclusions.

\section{Conflicts of Interest}

The author declares no conflicts of interest regarding the publication of this paper. 


\section{References}

Almulla, M., \& Bradbury, M. E. (2019). Auditor, Client, and Investor Consequences of the Enhanced Auditor's Report. Working Paper, New Zealand: Massey University. https://doi.org/10.2139/ssrn.3165267

Bentley, J. W., Lambert, T. A., \& Wang, E. (2018). The Effect of Increased Audit Disclosure on Managerial Decision Making: Evidence from Disclosing Critical Audit Matters. Working Paper. https://doi.org/10.2139/ssrn.3000978

Brasel, K., Doxey, M. M., Grenier, J. H. et al. (2016). Risk Disclosure Preceding Negative Outcomes: The Effects of Reporting Critical Audit Matters on Judgments of Auditor Liability. The Accounting Review, 91, 1345-1362. https://doi.org/10.2308/accr-51380

Francis, J. R. (2011). A Framework for Understanding and Researching Audit Quality. Auditing: A Journal of Practice \& Theory, 30, 125-152. https://doi.org/10.2308/ajpt-50006

Kachelmeier, S. J., \& Valentine, S. K. (2017). The Disclaimer Effect of Disclosing Critical Audit Matters in the Auditor's Report. Working Paper. https://doi.org/10.2139/ssrn.2481284

Köhler, A. G., Ratzinger-Sakel, N., \& Theis, J. C. (2016). The Effects of Key Audit Matters on the Auditor's Report's Communicative Value: Experimental Evidence from Investment Professionals and Non-Professional Investors. Working Paper. https://doi.org/10.2139/ssrn.2838162

PCAOB (2016). Proposed Auditing Standard-The Auditor's Report on an Audit of Financial Statements When the Auditor Expresses an Unqualified Opinion and Related Amendments to PCAOPB Standards. PCAOPB Release No. 2016-003, Washington DC: PCAOB.

Reid, L. C., Carcello, J. V., Li, C. et al. (2019). Impact of Auditor Report Changes on Financial Reporting Quality and Audit Costs: Evidence from the United Kingdom. Contemporary Accounting Research, 36, 1501-1539.

https://doi.org/10.1111/1911-3846.12486

Sirois, L. P., Bédard, J., \& Bera, P. (2018). The Informational Value of Key Audit Matters in the Auditor's Report: Evidence from an Eye-Tracking Study. Accounting Horizons, 32, 141-162. https://doi.org/10.2308/acch-52047 